\title{
Bazyli SIEGIEŃ
}

Białystok

\section{O POCHODZENIU NAZW OWADÓW W BIAŁORUSKO-UKRAIŃSKICH GWARACH PRZEJŚCIOWYCH NA BIAŁOSTOCCZYŹNIE}

Ujęcie etymologiczne leksyki gwarowej Białostocczyzny to stosunkowo nowy problem badawczy. Słownictwo omawianego obszaru jest niezwykle interesującym i cennym materiałem do dociekań naukowych. Pochodzące $z$ tzw. strefy bezpośredniego kontaktu utworzonej w wyniku wzajemnych wpływów dialektów wschodnio- i zachodniosłowiańskich, będące źródłem różnorakich procesów innowacyjnych, a także ze względu na peryferyczny charakter zachowujące zjawiska archaiczne, przedstawia nieocenioną wartość dla etymologii białoruskiej i słowiańskiej ${ }^{1}$. Wyniki gwarowych badań etymologicznych mogą posłużyć do poszerzania słowników etymologicznych konkretnego języka o dane dialektalne w postaci osobnych analizowanych jednostek leksykalnych bądź materiału ilustracyjnego dla etymologizacji danego języka ${ }^{2}$.

Przedmiotem badań w niniejszym artykule jest słownictwo gwarowe $\mathrm{z}$ zakresu nazw owadów. Podstawę analizy stanowi materiał językowy w przeważającej mierze zebrany bezpośrednio w terenie oraz w nieznacznym stopniu wyekscerpowany z Atlasu gwar wschodniostowianskich Białostocczyzny ${ }^{3}$. Terytorialnie obszar eksploracji został ograniczony do pasa białorusko-ukraińskich gwar przejściowych na Białostocczyźnie. Zgromadzoną leksykę entomologiczną (47 jednostek wyrazowych) poddano analizie etymologicznej, charakteryzując pochodzenie poszczególnych nazw na tle języków słowiańskich.



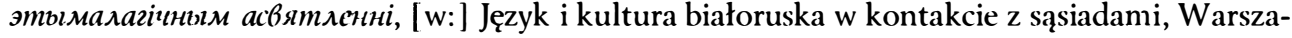
wa 2001, s. 47-53.

${ }^{2}$ Zob.: Ю.В. Откупшиков, Аиалектнъий материал и этимология, [w:] Этимология 1984, Москва 1986, с. 192.

${ }^{3}$ Są to jedynie nominacje gwarowe turkucia podjadka, pluskwy i gza bydlęcego. Zob.: Atlas gwar wschodniostowianiskich Białostocczyzny, t. V, Leksyka 1, Warszawa 1995, mapy 39, 46, 59.
} 
Badanie pochodzenia jednostek leksykalnych oparto w większości przypadków na istniejących już poglądach etymologicznych. Jedynie przy kilku nazwach, głównie stanowiących gwarowe innowacje leksykalne, przedstawiona analiza jest wynikiem własnych poszukiwań etymologicznych autora.

b'edrlonka 'biedronka siedmiokropka, Coccinella septempunctata; biedronka dwukropka, Adalia bipunctata'

Nazwa o niejednoznacznej etymologii. Najczęściej jej pochodzenie wiąże się z prasłow. przymiotnikiem *bedro 'mający plamy na biodrach' > 'plamisty, cętkowany, pstrokaty, łaciaty' wywodzącym się od *bedro 'biodro'. Dowodem na to ma być charakterystyczny wygląd biedronki sugerujący związek z pol. dial. biedrona, biedruna, biedrula 'nazwa krowy łaciatej', biedroń, biedrun 'wół łaciaty lub cętkowany', bierawa 'krowa łaciata, mająca plamy w okolicy bioder, grzbietu czy brzucha', ukr. dial. коза беəpa, бедраma 'z białą pręgą w poprzek (o krowie)'4. Inna wersja wskazuje na pochodzenie od prasłow. *vedro 'pogoda', a za podstawową formę uznaje się st.-pol. wiodrunka 'Ornithogalum umbellatum' utworzone od wiodro 'sucha słoneczna pogoda, upał' z prasłow. *vedro 'pogoda ${ }^{5}$. Swiadczyć o tym mają także północnosłowiańskie nazwy biedronki kojarzące się ze słońcem: d.-łuż. dial. styńcko, g.-łuż. bože stónčko, czes. slunéčko, ukr. сонеथкo $\sigma^{6}$. W literaturze naukowej bytuje również pogląd, na podstawie którego czeskie nazwy tego owada zostały utworzone od wyrazu beran 'baran', por. czes. beruška, czes. dial. bedruňka, bedrunka ${ }^{7}$. Poza polskim i czeskim obszarem językowym pokrewne

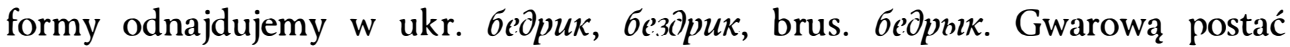
b'edronka, jak również brus. dial. бeəpoнкa, należy traktować jako polską pożyczkę z uwagi na obcy językom wschodniosłowiańskim przyrostek -onk $a^{8}$.

$\boldsymbol{b}^{\dagger}$ oža kor uouka 'biedronka siedmiokropka, Coccinella septempunctata; biedronka dwukropka, Adalia bipunctata'

Nazwa powstała $\mathrm{w}$ oparciu o wierzenia religijne dawnych Słowian i Germanów, według których biedronka uważana była za 'zwierzątko boże', por. pol. boża krówka, słowac. pánbožková krvavička, ros. божья коровка, brus. божая

\footnotetext{
${ }^{4}$ W. Boryś, Stownik etymologiczny języka polskiego, Kraków 2005, s. 27.

${ }^{5}$ A. Bańkowski, Etymologiczny stownik języka polskiego, t. 1, Warszawa 200(), s. 47.

${ }^{6}$ Zob.: W. Budziszewska, Stowianskie stownictwo dotyczace przyrody żywej, Wrocław-WarszawaKraków 1965, s. 160.

${ }^{7}$ F. Sławski, Stownik etymologiczny języka polskiego, t. I, z. 1, Kraków 1983, s. 32; W. Budziszewska, Stowianiskie stownictwo..., s. 159.

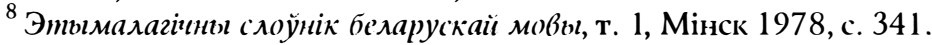


кароўка, bułg. божа кръаһиєка, a także niem. Herrgottkühlein ${ }^{9}$. Odwołanie do Boga $\mathrm{w}$ nazwie owada pojawiło się $\mathrm{z}$ chwilą przyjęcia chrześcijaństwa i ugruntowania go w masach ludowych, zastępując wcześniejsze 'słońce" ${ }^{\text {,0 }}$ (patrz wyżej).

\section{błoxla 'pchła, Pulex irritans'}

Nazwa ogólnosłowiańska pochodząca od prasłow. *blacha. Największe zmiany fonetyczne widoczne w polszczyźnie i językach łużyckich, por. pol. pchła, d.-łuż. pcha, g.-łuż. pcha, tka (w wyniku metatezy i upodobnienia pod względem dźwięczności grupy spółgłoskowej: $p c h t<b t c h$ ). W pozostałych językach nastąpiła wokalizacja $z$ lub utrzymanie sonantycznego $l$, por. czes. blecha, st.-czes. blcha, słowac. blcha, ros. блоха, ukr. блоха, блиха, brus. бльхха, блаха, słoweń. bólha,

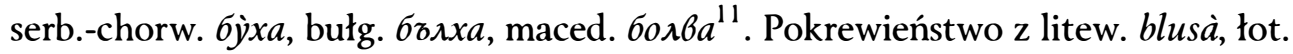
blusa, afg. vraža, st.-iran. *brušā 'pchła', a także grec. psýlla, psýllēs, łac. pūlex 'pchła' wskazuje na i.-e. *bhlusā 'pchła' ${ }^{2}$. Gw. błoxla ilustruje charakterystyczną dla języków wschodniosłowiańskich wokalizację $\approx$ w postaci $o$.

błošč

Postać $\mathrm{z}$ nagłosowym $b$ - jest charakterystyczna wyłącznie językom wschodniosłowiańskim, por. ukr. блоцциця 'pluskwa; pchła', brus. блаиııьıза 'pluskwa; pchła', dial. блаuıbıуa 'pluskwa', ros. dial. блоццица 'pluskwa'. Nazwy ukraińskie i białoruskie świadczą o semantycznym i, w pewnym stopniu etymologicznym, związku z prasłow. *bəlcha 'pchła' (ukr. блoxa, brus. блaxa). Dawne *bloščica miało powstać jako twór sufiksalny od formy deminutywnej *bləšbka $\left(<{ }^{*} b\right.$ zlcha) z przyrostkiem -ica w pierwotnym znaczeniu 'pchła' ${ }^{13}$. Wspomniana spółgłoska $b$ - w nagłosie mogła się też pojawić nie z podstawy słowotwórczej *bəlcha, a jedynie pod jej wpływem, w formie wyjściowej *ploščica 'pluskwa', co, w znacznej mierze, potwierdzałyby: pol. płoszczyca, płoszczka 'pluskwa', czes. ploštice, dial.

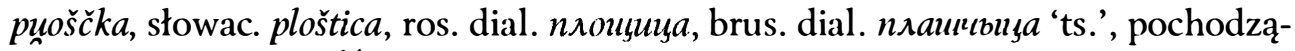
ce od *plosk- 'płaski' ${ }^{14}$. Dopuszcza się też pokrewieństwo wschodniosłowiańskiej nazwy tego owada z bałt. *blaska- 'płaski', litew. blãké 'pluskwa', łot. blakts 'ts. ${ }^{\text {, }}$.

\footnotetext{
${ }^{9}$ Tamże, s. 342 .

${ }^{10}$ W. Budziszewska, Stowiańskie stownictwo..., s. 160.

${ }^{11}$ Tamże, s. 142-143.

12 Ээтьмалагієныь слоўнік беларускай..., т. 1, с. 363; W. Boryś, Stownik etymologiczny..., s. 420.

13 Этымалагічны слоўнік беларускай..., т. 1, с. 358.

${ }^{14}$ A. Bańkowski, Etymologiczny stownik..., t. 2, s. 628.

${ }^{15}$ М. Фасмер, Этимологический словарь русккого язика, т. I, Сангт-Петербург 1996, с. 177.
} 
boyk 'trzmiel ziemny, Bombus terrastris'

Wyraz pochodzi od prasłow. dial. *bgkz 'to, co wydaje niski, przeciągły głos' i jest rzeczownikiem odczasownikowym utworzonym na gruncie prasłowiańskim od dźwiękonaśladowczego ${ }^{*} b g k a t i^{16}$. Nazwa o charakterze zachodniosłowiańskim, por. pol. bąk 'giez; trzmiel; truteń', kasz. bgk 'bąk', d.-łuż. daw. buk 'gat. owada', czes. dial. buk, bunk 'bąk; giez', słowac. búk 'ptak Ardea'. Z obocznym $u$ i często $\mathrm{w}$ formacjach sufiksalnych występuje w innych językach słowiańskich: ros. буıень 'bąk' (ptak i owad), букаиєка 'chrząszcz; robaczek; żuczek', brus. бука 'robaczek', serb. bukawac 'bąk (ptak)', czes. bukač 'bąk'17, a także serb.-chorw. $\sigma \hat{y} \kappa$ 'miejsce wodospadu, gdzie woda hucząc opada' ${ }^{18}$. Gwarowa forma boøk wskazuje na zapożyczenie z języka polskiego.

bz' 3 iel' 'pluskwiak tarczopodobny koloru zielonego, owad Heteroptera'

Wyraz pochodzi o czasownika $b z^{\prime} d^{\prime}$ 'iet' $i$ 'bździeć, puszczać wiatry' z prasłow. *bzzdèti 'pedere' ${ }^{19}$, powstał jako nazwa wykonawcy czynności z przyrostkiem -el (gw. - $-\overrightarrow{i e})$. Pierwotne znaczenie 'człowiek puszczający wiatry' przeniesione na owada ze względu na wydzielany przez niego przykry zapach, odór. W postaci $6 з д з і л ь$, a także бздуль, бздюль, бздзюx i pokrewnych zanotowany w gwarach środkowej i południowo-wschodniej Białorusi ${ }^{20}$. Nazwę tą należy odnieść do semantycznych innowacji gwarowych.

bzy(m)kotuxa 'mucha plujka, Calliphora vornitoria; mucha niebieska, Calliphora vicina'

Nazwa została utworzona od czasownika dźwiękonaśladowczego $b z y(m) k o t$ 'at'i 'bzyczeć, brzęczeć' i używana jest do określenia muchy plujki, inaczej zwaną muchą niebieską, z uwagi na fakt, że właśnie ten gatunek muchówek wyróżnia się donośnym, często dokuczliwym, bzyczeniem, brzęczeniem. Leksem odnotowano tylko w analizowanym materiale językowym, pod względem semantycznym należy uznać go za innowację gwarową.

\footnotetext{
${ }^{16}$ W. Boryś, Stownik etymologiczny..., s. 24.

${ }^{17}$ A. Brückner, Stownik etymologiczny języka polskiego, Kraków 1927, s. 19.

${ }^{18}$ F. Sławski, Stownik etymologiczny..., t. I, z. 1, s. 29.

${ }^{19}$ W. Boryś, Stownik etymologiczny..., s. 50.

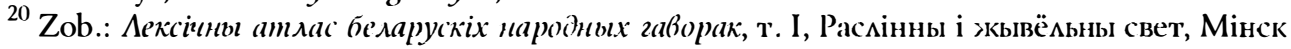
1993, mapa 361 .
} 
xrušč 'chrabąszcz majowy, Melolontha melolontha'

Wyraz pochodzi od prasłow. ${ }^{*}$ chrgstr, ${ }^{*}$ chrgščs $(<*$ chrgst-jo), które jest regularnym, z wokalizmem -o-, tworem imiennym od prasłow. czasownika *chręstiti 'chrzęścić; wydawać, powodować chrzęst, trzaski'21. Występuje w językach wschodniosłowiańskich, por. ros. xpyuı 'chrząszcz, chrabąszcz majowy', brus. xpyuı 'chrabąszcz majowy', ukr. xpyuı 'chrząszcz', st.-rus. xpyuıb 'ts.', a także w tym samym znaczeniu: czes. chroust, słowac. chrúst, serb.-chorw. daw. xpyum, słoweń. hrọ́šč Niektóre języki słowiańskie kontynuują pokrewną prasłow. nazwę wykonawcy czynności * chręščs ( < chręst-jo) utworzoną również tego samego czasownika pochodzenia dźwiękonaśladowczego *chręstiti, por. pol. chrzqszcz, połab.

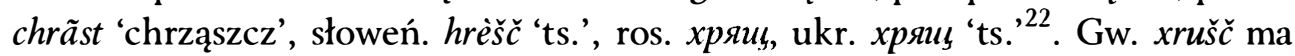
niewątpliwie charakter wschodniosłowiański.

červ 'czerw pszczeli', pl. č erv'i 'larwy muchy i innych owadów'

Jednostka leksykalna o zasięgu ogólnosłowiańskim, kontynuująca prasłow. *čŕvb 'robak, larwa owadów', por. pol. czerw 'larwa owadów; czerw pszczeli', d.-łuż. cerww 'robak; czerw pszczeli', g.-łuż. čerw 'robak; larwa', st.-czes. črv 'robak',

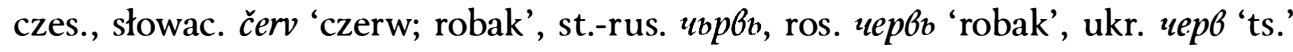
słoweń. črv 'ts.', serb.-chorw. upp̧ 'ts.', bułg. ıервeŭ 'robak; czerw', maced. upb 'ts. '23. Wyraz pozostaje w niewątpliwym związku z prasłow. *črms 'robak, czerw', mającym dokładne odpowiedniki w innych językach indoeuropejskich: litew. kirmis, kirmis 'robak, czerw', łot. cirmis 'robak; gąsienica', st.-ind. kirmis 'robak, czerw', pers. kirm 'robak' i kontynuującym i.-e. * $k^{u} r m i$ - 'robak, czerw'. Niewyjaśnione jest jednak pochodzenie $-\boldsymbol{v}$-. Przypuszcza się, że może tu chodzić o prastarą i.-e. oboczność przyrostków ${ }^{*}-m-\mathrm{i}^{*}{ }_{-} \mathrm{n}_{-}{ }^{24}$.

$\check{\boldsymbol{c}} \boldsymbol{e r v}$ ' ak 'robak; dżdżownica; larwa muchy i innych owadów'

Wyraz stanowi wschodniosłowiańską innowację słowotwórczą, por. ros.

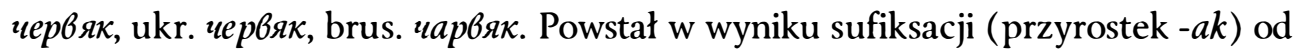
červ (patrz wyżej), zachowując w istocie jego pierwotne znaczenie.

\footnotetext{
${ }^{21}$ F. Sławski, Stownik etymologiczny..., t. I, z. 1, s. 85.

${ }^{22}$ М. Фасмер, Этимологический словарь..., т. IV, с. 279, 281; W. Boryś, Stownik etymologiczny..., s. 70.

${ }^{23}$ М. Фасмер, Этимологический слобарь..., т. IV, с. 335-336.

${ }^{24}$ W. Boryś, Stownik etymologiczny..., s. 96.
} 
čm'iel' 'trzmiel ziemny, Bombus terrastris'

Wyraz powstał na gruncie prasłowiańskim jako nazwa wykonawcy czynności z przyrostkiem *-elb, *-el' $b$ od podstawy wywodzącej się z i.-e. dźwiękonaśladowczego pierwiastka ${ }^{*} k e m-{ }^{*} k o m$ - 'brzęczeć, bzyczeć ${ }^{25}$. Prasłow. *č́melb, čomel' ' 'trzmiel' dziś spotykamy we wszystkich, poza bułgarskim, językach słowiańskich. W niektórych z nich dokonały się przekształcenia w grupie spółgłosek w nagłosie wyrazu oraz pewne zróżnicowanie morfologiczne w języku czeskim i jego dialektach, por. pol. trzmiel, kasz. čmèl, přčmél, přmél, d.-łuż. čmjel, tśmél,

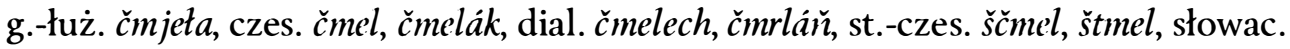

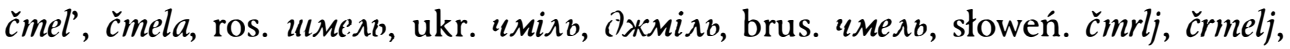

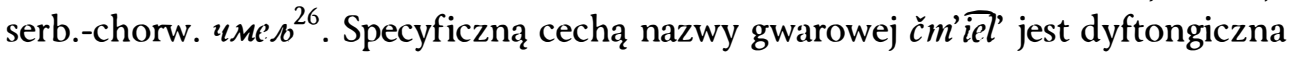
postać samogłoski rdzennej.

c'ma 'ćma, motyl nocny, owad Frenatae'

Wyraz związany z prasłow. *toma 'ciemność. Znaczenie 'motyla nocnego', poprzez przeniesienie określenia ciemności, mroku na owada latającego w ciemności, rozwinęło się jedynie w języku polskim. $\mathrm{Z}$ tego powodu nazwę gw. c'ma należy uważać za pożyczkę z polszczyzny. Świadczy o tym także nagłosowe miękkie $c$ '-, nietypowe dla systemu wokalicznego omawianych gwar, które konsekwentnie bądź zachowują dawne palatalne $t^{\prime}$ w formie półmiękkiego $t^{\prime}$ (np.: $t^{\prime} i x o$,

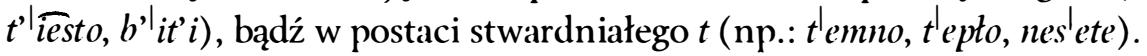

g'es 'giez bydlęcy, Hypoderma bovis'

Nazwa wyłącznie polska, pochodząca od prasłow. dial. *gøzo 'giez, ślepak, bąk’, najczęściej interpretowana jako wyraz dźwiękonaśladowczy. Z języka polskiego zapożyczone do ukraińskiego i słowackiego, por. ukr. $2 e \partial_{3}, 2 e \partial_{3}, z e z_{3}$ ' 'giez', słowac. dial. gzec, gzel 'wiercipięta, człowiek ruchliwy'27. Apofoniczne formy do pol. giez (*gzzъ) występują w brus. ziз (*gyzъ) 'mucha, ślepak', ziж (*gyžı) 'owad Oestrus' i d.-łuż. gizk 'ślepak, owad', wszystkie utworzone od podstawy * $g y z-{ }^{28}$. Wybuchowa spółgłoska $g$ i kontynuant dawnego $r \mathrm{w}$ postaci samogłoski $e \mathrm{w}$ formie gwarowej g'es wskazuje na jej zapożyczenie z języka polskiego.

\footnotetext{
${ }^{25}$ Tamże, s. 650 .

${ }^{26}$ Zob.: W. Budziszewska, Stowiańskic' stownictwo..., s. 145.

${ }^{27}$ W. Boryś, Stownik etymologiczny..., s. 160.

28 Эmьммалагієнь слоунік бе ларускаиі..., т. 3, с. 82, 83.
} 


\section{$\boldsymbol{h n}^{\prime}$ 'ida 'jajko wszy'}

Jednostka leksykalna o zasięgu ogólnosłowiańskim, por. pol. gnida, czes. hnida, słowac. hnida, g.-łuż. hnida, d.-łuż. gnida, ros. әнида, ukr. гнида, brus. әнi-

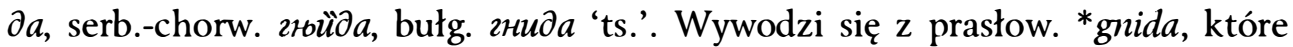
$\mathrm{z}$ i.-e. ${ }^{*} g^{h} n \overline{\mathrm{I}} d \bar{a}$ 'gnida', należącego najprawdopodobniej do praindoeuropejskiego pierwiastka * $g^{h}$ en- 'trzeć, rozcierać; coś rozdartego, drobnego, małego, odrobina'. Wskazują na to choćby takie formy jak: litew. glinda $\left(<{ }^{*}\right.$ gninda) 'gnida', łot. gnĩda 'ts.', st.-isl. gnit 'ts. ${ }^{29}$. Według innej wersji wyraz ten pozostaje w związku z prasłow. ${ }^{*}$ gniti ${ }^{30}$.

kl' iešč 'kleszcz pospolity, Ixodes ricinus'

Nazwa tego pajęczaka ma charakter ogólnosłowiański. Prasłow. *klěšč $\left(<{ }^{*} k l e \check{s t}-j b\right)$ jest formacją oznaczającą wykonawcę czynności powstałą od czasownika *klěstiti 'ściskać, zgniatać, np. kleszczami’ przez dodanie przyrostka -jb. Wspomniany czasownik zaś wywodzi się od i.-e. *klęnk- '(boleśnie) ściskać, uciskać, zgniatać, szczypać ${ }^{31}$. Obecnie znany jest w większości języków słowiańskich: połab. klest, kléstak, d.-łuż., g.-łuż. klěšć 'kleszcz, wesz psia', pol. kleszcz,

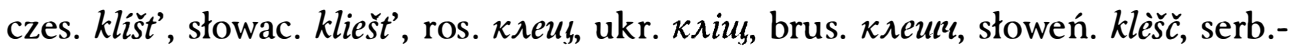
-chorw. K^êuım 'ts.' ${ }^{32}$. Wersja gwarowa odzwierciedla dyftongiczną realizację dawnego $\check{e}$.

\section{kom'ar 'komar pospolity, Culex pipiens'}

Kolejna nazwa występująca w całej Słowiańszczyźnie i w tym samym znaczeniu, por. pol. komar, czes. komár, słowac. komár, d.-łuż. daw. komar, ros. комap, st.-rus. комаръ, ukr. комар, brus. камар, słoweń. komár, serb.-chorw. ко̀мâp, bułg. комáp. Wyraz powstał na gruncie prasłowiańskim (*komarz) najprawdopodobniej od i.-e. dźwiękonaśladowczego pierwiastka *kem-, *kom- 'brzęczeć, bzyczeć' z pierwotnym znaczeniem '(uporczywie) brzęczący owad'33. Swiadczą o tym prapokrewne formy: st.-prus. camus 'trzmiel', litew. kamãne 'trzmiel', dial. kamine 'dzika pszczoła', łot. kamane, kamene 'trzmiel, dzika pszczoła' i, w dalszej kolejności, śr.-w.-niem. hummen, niem. hummen 'brzęczeć', st.-w.-niem. humbal 'trzmiel' ${ }^{34}$. W języku prasłowiańskim obok formy *komaro istniała także postać

\footnotetext{
${ }^{29}$ W. Boryś, Stownik etymologiczny..., s. 168.

${ }^{30}$ Zob.: М. Фасмер, Этимологическиї словарь..., т. I, с. 421; Этьмалагіинь слоўнік беларускай..., т. 3, с. 98-99.

31 W. Boryś, Stownik etymologiczny..., s. 234.

${ }^{32}$ Zob.: W. Budziszewska, Stowianiskie stownictwo..., s. 148.

${ }^{33}$ W. Boryś, Stownik etymologiczny..., s. 246.

${ }^{34}$ М. Фасмер, Ээиммологический (лоһарь..., т. II, с. 30)1.
} 
*komorz (z przyrostkiem -orz), reliktowo zachowana w st.-pol. i st.-łuż. komor ${ }^{35}$, częściej interpretowana jako wtórna, powstała prawdopodobnie w skutek upodobnienia samogłosek ${ }^{36}$.

\section{kov'al' 'mrówka rudnica, Formica rufa'}

Nazwa tej dużej mrówki leśnej swym zasięgiem obejmuje jedynie białorusko-ukraińskie gwary przejściowe na Białostocczyźnie. Jest to swoista innowacja semantyczna, polegająca na przeniesieniu nazwy z kowala 'człowieka zajmującego się kuciem, obróbką żelaza' na owada. Przyczyny tego procesu pozostają niejasne. Być może chodzi tu o odwołanie się do siły kowala, którą powinien dysponować człowiek zajmujący się tym rzemiosłem. Taką siłę posiada mrówka rudnica. Z racji swej wielkości jest ona dużo silniejsza od swej „kuzynki” hurtnicy pospolitej.

\section{krüot 'turkuć podjadek, Gryllotalpa gryllotalpa'}

Wyraz wywodzi się od prasłow. *krotz 'kret'. Dalsza etymologia jest niejednoznaczna. Jedna z wersji wskazuje na pokrewieństwo z litew. kertùs, kertùkas, kirstùkas 'ryjówka' i bardziej odległym fonetycznie i morfologicznie litew. kùrmis 'kret', wiążąc wyraz słowiański z prapostacią *krŭ-to-, powstałą od i.-e. * (s)ker-t'ciąć, dłubać' na bazie pierwiastka *(s)ker- 'ciąć, odcinać, oddzielać'. Nazwa pierwotnie miała oznaczać 'zwierzę dłubiące, ryjące w ziemi' ${ }^{37}$. Według innej interpretacji, istnieje związek z litew. krutùs 'ruchliwy, żwawy', krutéti, krutù 'ruszać się, pracować', co skłania do określenia pierwotnego znaczenia jako 'zwierzątko ruchliwe ${ }^{38}$. We współczesnym znaczeniu 'kret, Talpa europaea' nazwa obejmuje wszystkie języki słowiańskie, por. pol. kret, czes. krtek, st.-czes. $k r t$, słowac. $k r t$, d.-łuż. kšet, škret, g.-łuż. knot (z *krot), ros. кpom, ukr. кpom, brus. кpom, słoweń.

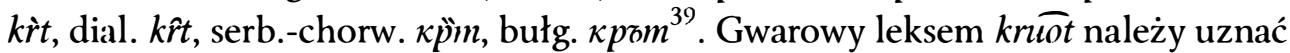
za innowację semantyczną, stanowiącą formę homonimiczną, w pierwszej kolejności, do wschodniosłowiańskich jednostek wyrazowych.

\footnotetext{
${ }^{35}$ A. Bańkowski, Etymologiczny stownik..., t. 1, s. 764.

${ }^{36}$ F. Sławski, Stownik etymologiczny..., t. II, s. 377.

${ }^{37}$ W. Boryś, Stownik etymologiczny..., s. 258.

${ }^{38}$ М. Фасмер, Этиммологиче'ский словарь..., т. II, с. 383; F. Sławski, Stownik etymologiczny..., t. III, s. 92-93.

${ }^{39}$ Zob.: W. Budziszewska, Stowiańskic stownictwo..., s. 86-87.
} 


\section{kus'ušča m'uxa 'gatunek muchy'}

Nazwa analityczna, odnosi się do owada z rodziny muchówek, żywiącego się krwią człowieka lub zwierzęcia. Decydującym o znaczeniu terminu jest pierwszy z jego członów. Został on utworzony od czasownika kus at'i 'kąsać, gryźć' jako imiesłów czynny czasu teraźniejszego. Od strony semantycznej derywat ten wskazuje na sposób odżywiania się owada, który przy zdobywaniu pokarmu kąsa swą ofiarę, nakłuwa jej skórę przystosowanym do tego narządem. Określenie to odnotowano tylko w białorusko-ukraińskich gwarach przejściowych Białostocczyzny.

kuzlaka 'ogólna nazwa używana do oznaczania owadów, w szczególności nieznanych'

Wyraz pochodzenia wschodniosłowiańskiego. Identycznie brzmiącą nazwę zachowują gwary poleskie i południowo-zachodni dialekt języka białoruskiego, por. brus. кузака 'owad, myszka, robaczek'. Pokrewne semantycznie określenia to: ros. козяљка, brus. кузулька 'ошаd', кузурка 'robak, robaczek', казяука 'ts.' Etymologię wszystkich tych jednostek leksykalnych wywodzi się od słowa koza (w wyniku podobieństwa czułków owada do rogów zwierzęcia ${ }^{40}$ ). Formacja gw. kuzlaka wskazuje na stratę sufiksalnego - $v$ - w wyniku uproszczenia pierwotnej prawdopodobnej postaci *kozavka, kuzavka ${ }^{41}$. Przejście bezprzyciskowego $o$ w $u$ to efekt tzw. ukania (por. gw. kun'ec 'koniec', kunplan' ina 'towarzystwo; przyjaciele'), odmiennie niż w formach brus. кузулька, кузурка, gdzie $u$ w rdzeniu pojawiło się w rezultacie upodobnienia do samogłoski przyrostkowej ${ }^{42}$. Opisane przekształcenia wokaliczno-morfologiczne świadczą o innowacyjnym charakterze tego leksemu gwarowego.

\section{mat ytka 'motyl, owad Lepidoptera'}

Wyraz wywodzi się z prasłow. *motyl'b utworzonego od *mesti 'wiać, rozwiewać, kołysać, *motati 'motać, kręcić, potrząsać, kołysać' z pierwotnym znaczeniem 'taki, który lata nierówno, trzepocąc ${ }^{43}$. W tej postaci (z samogłoską rdzenną $o$ i przyrostkową $y$ ) występuje w językach zachodnio- i wschodniosłowiańskich, por. pol. motyl, czes. motýl, słowac. motýl, ros. мombııь 'larwa komara', ukr. мотиль, brus. матьıљь 'motyl; larwa komara', często też w nowszych formacjach sufiksalnych, por. czes. motejlik, motilák, ros. мотьıёк 'mały motyl', brus. матьıёк 'motyl'. Języki południowosłowiańskie kontynuują formy prasłow.

\footnotetext{
${ }^{40}$ М. Фасмер, Этилологический словарь..., т. II, с. 279.

${ }^{41}$ Zob.: Этьммалагіпиы слоўнік беларускайі.., т. 5, с. 147.

${ }^{42}$ Tamże, s. 148.

${ }^{43}$ W. Boryś, Stownik etymologiczny..., s. 338.
} 
${ }^{*}$ metyl'b, *metul'v, por. słoweń. metúlj 'motyl', serb.-chorw. Mèmus 'choroba owiec (fasciola hepatica)', bułg. метил 'ts.', maced. метил 'ts.' Odnajdujemy je także w g.-łuż. mjetel, 'motyl', ros. dial. метелек, метелик, метьль 'motyl; choroba owiec', ukr. метелuк 'motyl'. Powyższe przykłady świadczą również o istotnych różnicach semantycznych. Południowa Słowiańszczyzna rozwinęła tu znaczenie 'motylica, choroba owiec', natomiast na pozostałym obszarze dominuje znaczenie 'motyl'44. Forma mat'ytka jest gwarową innowacją słowotwórczą z przejściem rdzennej samogłoski $o$ w $a$ pod wpływem białoruskiego akania i depalatalizacją pierwotnie miękkiej spółgłoski $l$.

matyl' icy 'motylica, Fasciola hepatica; choroba bydła wywoływana przez tego pasożyta'

Nazwa utworzona przy pomocy przyrostka *-ica od podstawy * motyl'b. Jest to wyraz północnosłowiański, co potwierdzają następujące formy: pol. motylica 'pasożyt tej nazwy; choroba owiec', d.-łuż. mjatelica 'ćma', mjatelice 'robaki we wnętrznościach bydła', st.-czes. motylicě 'robak tej nazwy', czes. dial. motylice, motolice 'choroba owiec', słowac. motylica 'glista krowia lub owcza (wątrobiana)', ukr. мотилиця 'choroba owiec', brus. мamorлiıza 'motyl; choroba bydła'. Słoweń. metuljača 'ćma; trupia główka (gatunek ćmy)' - to bliski odpowiednik formalnoznaczeniowy ${ }^{45}$. Gwarowa postać została odnotowana tylko w formie liczby mnogiej matyl'icy.

m'oška 'mszyca, mszyce Aphidoidea; meszka, meszki Simulidae'

Nazwa jest pierwotnym zdrobnieniem z przyrostkiem *-ıka od prasłow. ${ }^{*} m \approx s \check{a}$ 'mucha ${ }^{46}$. W tej postaci sufiksalnej charakteryzuje przede wszystkim grupę ruską, por. ros. моикa 'maleńka muszka, przeważnie z tych, które piją krew', ukr. моиєка 'muszka, komar', brus. моиєка 'mszyca'. W języku polskim obok jednostki leksykalnej meszka 'drobny owad z rzędu muchówek, mustyk' występuje również inna forma deminutywna (z przyrostkiem *-ica) - mszyca, obejmująca swym zasięgiem pozostałe języki zachodniosłowiańskie, a także południowosłowiańskie, por. d.-łuż. p̌̌yca 'komar', czes. mšice 'mszyca', słowac. mšica 'ts.', słoweń. mešica 'komar; mszyca', serb.-chorw. мyıuıзa 'muszka', maced. мyıuııка 'drobna muszka; drobny owad' ${ }^{47}$. Oba dawne zdrobnienia (*møška i *mzšica) poprzez podstawę * $m$ š̌a są pokrewne z mającym inną samogłoskę rdzenną wyrazem

\footnotetext{
${ }^{44}$ W. Budziszewska, Stowiańskie' stownictwo..., s. 151.

${ }^{45}$ Tamże, s. 152.

${ }^{46}$ W. Boryś, Stownik etymologiczny..., s. 342.

${ }^{47}$ W. Budziszewska, Stowiańskie' stownictwo..., s. 146.
} 
mucha (prasłow. *mucha). Gw. m'oška ma niewątpliwie charakter wschodniosłowiański i jednoczy w sobie znaczenia 'mszyca' i 'meszka'.

mūl' 'mól włosieniczek, Tineola bisselliella; mól kożusznik, Tinea pellionella'

Dawna nazwa wykonawcy czynności z przyrostkiem *-jb. Prasłow. ${ }^{*}$ mol'b pochodzi od i.-e. *mel(2)- 'rozkruszać, rozdrabniać, mleć' z wymianą samogłoski rdzennej $e>o$. Pierwotne znaczenie 'ten, który rozdrabnia, miele' odnosiło się prawdopodobnie do toczących, niszczących coś gąsienic owadów, w pierwszej kolejności do gąsienic mola odzieżowego, żerujących na odzieży ${ }^{48}$. Wyraz ma charakter ogólnosłowiański, w większości języków występuje w tym samym znaczeniu, por. pol. mól, czes. mol, słowac. mol', ros., brus. ^ıоль, ukr. мi^s, słoweń. mòlj, serb.-chorw. мìs oraz pierwotnie deminutywne formy derywowane: ukr. мiльza, serb.-chorw. мòsalı, bułg. молeı, maced. молeц. W grupie łużyckiej obok podstawowego znaczenia 'mól' pod wpływem niem. dial. Motte 'mól; karaluch' nastąpił rozwój znaczenia 'karaluch', por. d.-łuż. mól, móla 'mól; karaluch; larwa pszczoły', g.łuż. mól, mola 'mól; karaluch'49 . Gw. muol' ilustruje realizację dawnego $o$ w postaci dyftongicznej.

m'uxa 'mucha, Musca domestica i inne gatunki tego owada'

Kolejna nazwa o zasięgu ogólnosłowiańskim, por. pol. mucha, czes. moucha, st.-czes. múcha, słowac. mucha, d.-łuż., g.-łuż. mucha, ros., ukr., brus. мyxa, słoweń. múha, serb.-chorw. мȳxa, bułg. мyxá. Wywodzi się z prasłow. *mucha, które, z kolei, jest kontynuacją i.-e. *mū-, *mus- 'komar, mucha' - wyrazu o charakterze dźwiękonaśladowczym, powstałego od odgłosu wydawanego przez latające owa$\mathrm{dy}^{50}$. Forma $m^{\prime} u x a$ pozostaje w ścisłym związku z nazwą $m^{\prime} \circ \varsigma_{k}$ (patrz wyżej), różni się jednak odmiennym pochodzeniem samogłoski rdzennej ${ }^{51}$.

\section{murav'el' 'mrówka, Formica'}

Nazwa pochodzi od prasłow. *morvbjo 'mrówka', z którego rozwinęło się st.-rus. моровии i współczesne postaci wschodniosłowiańskie: ros. муравеŭ, dial. муравель, ukr. муравель, brus. dial. муравель ${ }^{52}$. Oprócz nich w języku ukraińskim i białoruskim powstały formy innowacyjne, por. ukr. мураха, мураика, brus. мураика. Pozostałe języki słowiańskie kontynuują prasłow. ${ }^{*}$ morvv, w naj-

\footnotetext{
${ }^{48}$ W. Boryś, Stownik etymologiczny..., s. 339.

${ }^{49}$ W. Budziszewska, Stowiańskie stownictwo..., s. 145.

${ }^{50}$ W. Boryś, Stownik etymologiczny..., s. 342.

${ }^{51}$ Zob.: М. Фасмер, Этимологический словарь..., т. III, с. 19.

${ }^{52}$ Zob.: A. Bańkowski, Etymologiczny stownik..., t. 2, s. 219.
} 
bardziej archaicznej postaci zachowane na Łużycach (g.-łuż. mrowja, mrjowja, d.-łuż. mroja) i w nieco mniejszym stopniu w językach południowosłowiańskich (słoweń. mrávlja, mrâvec, mrâv, serb.-chorw. мpâb, bułg. мpába, мpabus, мpábкa, maced. мpaba). W językach polskim, czeskim i słowackim dziś występują wyłącznie dawne formy deminutywne, por. pol. mrówka, czes. mravenec, słowac. mravec, mravenec $^{53}$. Słowiańskie jednostki wyrazowe są pokrewne $\mathrm{z}$ nazwami tego owada w innych językach indoeuropejskich: st.-isl. maurr, śr.-irl. moirb, łac. formica, grec. mýrmēks, býrmāks, órmikas, awest. maorīš, maoiri-, ind. vamri, st.-ind. vamras. Wszystkie wymienione formy sprowadzają się do i.-e. *moruno-, *morŭr 'mrów$\mathrm{ka}^{, 54}$. Postać gwarowa murav' el' ma pochodzenie wschodniosłowiańskie ze zmianą sufiksalnej spółgłoski $j \mathrm{w} l$.

os' $\boldsymbol{a}$ 'osa pospolita, Vespa vulgaris'

Wyraz o pochodzeniu praindoeuropejskim (i.-e. * ${ }^{*} o b^{h} s \bar{a}$ 'osa') ${ }^{55}$. Postać prasłow. ${ }^{*}(v)$ osa kontynuują wszystkie języki słowiańskie. Dawne nagłosowe $v$ współcześnie pozostaje jedynie w językach łużyckich (d.-łuż. wósa, g.-łuż. wosa) i języku czeskim (vosa), pozostałe języki, poza ros. i brus. dial. ocba, wykorzystują identyczną pod względem morfologicznym nazwę tego owada, por. pol. osa, słowac. osa, ros., ukr. oca, brus. aca, słoweń. ósa, serb.-chorw. òca, bułg. ocá, maced. $o c a^{56}$. W innych językach indoeuropejskich występują pokrewne formy $\mathrm{z}$ pierwotnym początkowym $v$-, por. litew. vapsà, vapsvà, łot. vapsene 'osa', st.-prus. wobse, st.-w.-niem. wefsa, wafsa, wespa, niem. Wespe, łac. vespa ${ }^{57}$. Dalsza etymologia tej nazwy wskazuje na związek z i.-e. czasownikiem *uebh- 'tkać', sugerującym pierwotne znaczenie 'owad „tkający” swoje gniazda z włókien roślinnych, ${ }^{58}$.

\section{'ovad 'bąk bydlęcy, Tabanus bovinus'}

Nazwa nie posiada pewnej etymologii. Najbardziej wiarygodna i powszechna hipoteza traktuje prasłow. *ovadr jako złożenie wywodzące się z i.-e. *ov-ōdos 'owcojad', gdzie *ov- pochodzi od *ovis 'owca', a ${ }^{*} \bar{o} d-<* \bar{e} d-$ 'jeść ${ }^{59}$. Wyraz ma charakter ogólnosłowiański, obecnie występuje we wszystkich językach słowiań-

\footnotetext{
${ }^{53}$ W. Budziszewska, Stowianskie stownictwo..., s. 15()-151.

${ }^{54}$ W. Boryś, Stownik etymologiczny..., s. 340.

${ }^{55}$ Tamże, s. 396.

${ }^{56}$ W. Budziszewska, Stowiańskie' stownictwo..., s. 144-145.

${ }^{57}$ М. Фасмер, Этимологитескииі словарь..., т. III, с. 156.

58 A. Bańkowski, Etymologiczny stownik..., t. 2, s. 432; Emимологієиий словник українької мови, т. 4, Київ 2004, с. 217.

${ }^{59}$ М. Фасмер, Этимологический словарь..., т. III, с. 114; A. Bańkowski, Etymologiczny stownik..., t. 2 , s. 469 .
} 
skich, poza grupą łużycką. Jedynie w języku polskim posiada znaczenie ogólne 'owad', poza tym oznacza wyłącznie 'bąka, gza', por. pol. owad, czes. ovád, dial. hovad, hovád, st.-czes. ovad, słowac. ovad, obad, ros. (hiperpoprawne) ${ }^{60}$ obod, dial.

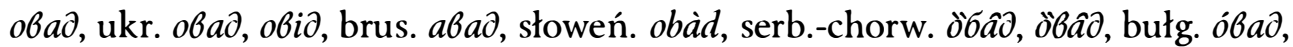
$a b a \partial, o b o \partial, o b z \partial, o \sigma o \partial z^{61}$. Słowiańskim formom są pokrewne litew. úodas 'komar', łot. uóds 'ts.' Wąskie znaczenie gwarowej jednostki leksykalnej wyklucza wpływ języka polskiego i umieszcza ją wśród nazw wschodniosłowiańskich.

'ovaden' 'bąk bydlęcy, Tabanus bovinus'

Wyraz o tym samym pochodzeniu co $\mathrm{i}$ 'ovad. Zapewne jest to dawna formacja sufiksalna z przyrostkiem ${ }^{*}$-snb, por. prasłow. ${ }^{*}$ obadons ' bąk ${ }^{, 62}$, dziś kontynu-

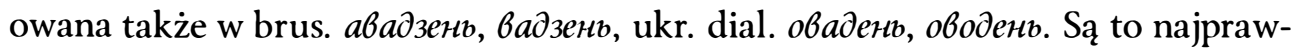
dopodobniej archaiczne wschodniosłowiańskie innowacje dialektalne.

\section{pa' uk 'pająk, owad Aranea'}

Nazwa kontynuująca prasłow. *pagkz, najczęściej interpretowane jako archaiczne złożenie z przedrostkiem * $p a$ - i niezachowanym starym rzeczownikiem odczasownikowym * $g k \delta$, pokrewnym łac. uncus 'krzywy hak', st.-ind. ariká- 'zgięcie, wygięcie' i sprowadzanym do i.-e. pierwiastka *ank-, *ang- 'zginać, wyginać'. Pierwotnie wyraz miał oznaczać 'istotę z krzywymi, zakrzywionymi nogami' ${ }^{63}$. We współczesnych językach słowiańskich nazwa tego owada pokazuje późne zróżnicowanie fonetyczne, związane w dużym stopniu z losami samogłoski $o$ oraz pojawieniem się spółgłosek protetycznych $v$ lub $j$. Na terenie północnosłowiańskim (poza grupą lechicką) dawne *o przeszło $\mathrm{w} u$, w większości języków wystąpiła proteza $v$, por. ukr. nabyк, brus. nabyк, czes. pavouk, słowac. pavuk, d.-łuż., g.-łuż. pawk, ale pol. pająk, kasz. pajik, pajk, połab. pójãk. Południowa Słowiańszczyzna (oprócz serb.-chorw. năŷk), podobnie jak język polski, rozwinęła protetyczne j: słoweń. pâjok, pâjok, bułg. nask, maced. najak ${ }^{64}$. Forma gwarowa nawiązuje bezpośrednio do archaicznej postaci st.-rus. naykz, utrzymanej do dziś jedynie w języku rosyjskim i dialektach języka białoruskiego i ukraińskiego, por. ros., brus. dial., ukr. dial. nayk.

\footnotetext{
${ }^{60}$ Zоb.: Этыммалагічны слоўнік беларускай..., т. 1, с. 67.

${ }^{61}$ W. Budziszewska, Stowianskie stownictwo..., s. 156.

${ }^{62}$ Этыммалагічны слоўнік беларускай..., т. 1, с. 68.

${ }^{63}$ W. Boryś, Stownik etymologiczny..., s. 408; Эmьıмалагінпь слоўнік беларускай..., т. 8, с. 93.

${ }^{64}$ W. Budziszewska, Stowiańskie stownictwo..., s. 143.
} 
$\boldsymbol{p}^{\prime}$ etryk, petrl ' 'biedronka siedmiokropka, Coccinella septempunctata; biedronka dwukropka, Adalia bipunctata'

Jedno z trzech określeń gwarowych biedronki (patrz b’edronka, b'oža

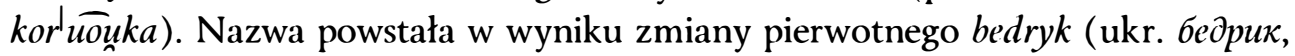

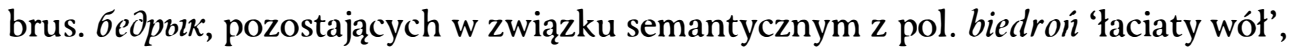
biedrona 'łaciata krowa' i in. ${ }^{65}$ ) pod wpływem imienia Petryk (ukr. Пempuк) ${ }^{66}$. Forma petro jest rezultatem dalszego zbliżenia $\mathrm{z}$ antroponimem Petro (ukr. Петро). Zasięg tej innowacji wskazuje na jej ukraińsko-białoruski charakter.

pol'iz'oxa 'owad z rodziny muchówek'

Nazwa powstała na gruncie języka gwarowego od czasownika pol'iz'at'i 'polizać'. U podstawy motywacji leży sposób pobierania pokarmu przez owada: muchy określane tym mianem jakby zlizują pokarm przy pomocy odpowiednio przystosowanego narządu, nie kąsając przy tym i nie gryząc. Pod względem semantycznym i słowotwórczym wyraz należy do specyficznych cech gwarowego nazewnictwa owadów omawianego terenu.

prus ak 'karaczan prusak, Blatella germanica'

Określenie pochodzi od etnonimu Prusak 'mieszkaniec Prus' ${ }^{97}$. W znaczeniu 'karaluch' występuje w polszczyźnie i językach wschodniosłowiańskich, por. pol. prusak, ros. прусак, ukr. прусак, brus. прусак. Nazwa tego owada powstała w skutek kondensacji związku wyrazowego pruski karaluch, por. niem. deutsche Schabe 'prusak, karaluch' (dosłownie: niemiecki karaluch). Na obszar północnej Słowiańszczyzny wyraz został zapożyczony z języków bałtyckich, por. st.-prus. prũsis 'Prusak', litew. prúsas ‘Prusak; karaluch', łot. prüsis 'ts.' Do języków ruskich trafił za pośrednictwem języka polskiego ${ }^{68}$.

pščot'a 'pszczoła miodna, Apis mellifica'

Kolejna nazwa wywodząca się z prasłowiańszczyzny. Przy analizie jej pochodzenia wyodrębnia się dźwiękonaśladowczy rdzeń *bðk-, *bヶč- związany z prasłow. *bučati 'brzęczeć'. Utworzony przy pomocy przyrostka *-ela derywat * brčela miałby pierwotnie oznaczać 'tą, co brzęczy' ${ }^{69}$. Inna wersja wychodzi z rekonstrukcji pierwotnej prasłow. prapostaci *bbčela (< i.-e. *bhein-) i wskazuje na

65 Этьммалагіины слоўнік беларускай..., т. 1 , с. 342

${ }^{66}$ Етимологічний словник української..., т. 4, с. 361-362.

${ }^{67}$ М. Фасмер, Этимологичи'скииі словарь..., т. III, с. 389.

${ }^{68}$ Етимологічиий словицк українькой..., т. 4, с. 617.

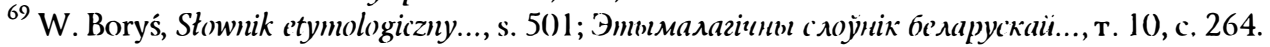


związek z nazwami tego owada w części języków indoeuropejskich, por. litew. bitè, st.-w.-niem. bini, niem. Biene, st.-irl. bech, szwedz. bi, ang. bee ${ }^{70}$. Obecne formy słowiańskie odzwierciedlają różne zmiany fonetyczne w nagłosie wyrazu. Pod tym względem największe przekształcenia pierwotnej postaci zaszły w językach północno-zachodnio-słowiańskich oraz ukraińskim i słoweńskim, por. pol. pszczoła, kasz. pščoła, połab. céla, cưóla, d.-łuż. coła, g.-łuż. pčoła, wčoła, czes., słowac. včela, ukr. бӘжола, słoweń. čebẹla, čmela ${ }^{71}$. W pozostałych językach wschodnio- i południowosłowiańskich doszło głównie do ubezdźwięcznienia spółgłoski


Nagłosowa grupa spółgłoskowa gw. pščł $a$ wskazuje na zapożyczenie leksemu z języka polskiego ${ }^{72}$.

$\boldsymbol{r o b}^{\mid} \boldsymbol{a k}$ 'robak, gąsienica, dżdżownica'

Wyraz jest uważany za zachodniosłowiański, pierwotnie występujący z nagłosowym ch-, por. st.-pol. chrobak, robak, pol. robak, czes. chrobák 'żuk', słowac. chrobák 'żuk, motyl', ukr. гробак, робак 'robak, dżdżownica', brus. paбaк 'robak, gąsienica, dżdżownica'. Prasłow. * chrobakz zostało utworzone przy pomocy przyrostka *-akr od czasownika pochodzenia dźwiękonaśladowczego *chrobati 'trzeszczeć, chrzęścić, chrupać' i posiadało znaczenie 'ten, co chrzęści, chrupie ${ }^{, 73}$. Dziś semantycznie najbliższe są mu nazwy w grupie czesko-słowackiej z rozwojem znaczenia ‘żuk'. Pol. robak utraciło spółgłoskę ch- w nagłosie i współcześnie oznacza 'drobne zwierzę bezkręgowe, o wydłużonym kształcie ciała'. Pod względem formalno-znaczeniowym niemal tożsame są mu odpowiedniki ukraińskie i białoruskie. Ta ich bliskość skłania do przypuszczeń, że są to zapożyczenia $\mathrm{z}$ języka polskiego ${ }^{74}$. Do pożyczek z polszczyzny należy także gw. roblak.

\section{$\boldsymbol{s}^{\prime} \mathbf{l}^{\prime}$ ip ${ }^{a k}$ 'ślepak pospolity, Chrysops caucutiens'}

Wyraz występuje w językach północnosłowiańskich i wykazuje pewne zróżnicowanie morfologiczne i semantyczne. W grupach wschodniosłowiańskiej i łużyckiej oznacza 'bąka bydlęcego, por. ros. cлеneнь, brus. сляneнъ, c^яniua, ukr. сліnень, dial. сліnaк, g.-łuż. slepc, d.-łuż. slěpc ${ }^{75}$. W polszczyźnie spotykamy go znaczeniu 'owad Chrysops', por. pol. ślepak, ślepień. Nazwa pochodzi od

\footnotetext{
${ }^{70}$ A. Bańkowski, Etymologiczn.y stownik..., t. 2, s. 523; М. Фасмер, Этимологический словарь..., T. III, c. 416.

${ }^{71}$ W. Budziszewska, Stowianskie stownictwo..., s. 70.

${ }^{72}$ Zob.: Этыммалагіины слоўнік беларускай..., т. 10, с. 264.

${ }^{73}$ W. Boryś, Stownik etymologiczny..., s. 515.

${ }^{74}$ Этьммалагієни слоўнік беларускай..., т. 11, с. 8.

${ }^{75}$ W. Budziszewska, Stowiańskie stownictwo..., s. 157.
} 
przymiotnika ślepy (gw. s'l'iply) i motywowana jest zachowaniem się owada, który, wpijając się w skórę zwierzęcia, staje się jakby ślepy, można go zdjąć nie wystraszając $^{76}$. Semantyka jednostki gwarowej $s^{\prime} l^{\prime} i p \mid a k$ wskazuje na możliwość pożyczki z języka polskiego.

st'onka 'stonka ziemniaczana, Leptinotarsa decemlineata'

Nazwa niewątpliwie jest zapożyczeniem z języka polskiego. Swiadczą o tym odpowiedniki wschodniosłowiańskie odwołujące się w oznaczaniu tego owada do jego pochodzenia, por. ros. колорадский жук, ukr. колорадський жук, brus. каларадскі жук, a także inną polską nazwę: chrząszcz kolorado. Stonka to nazwa sztuczna, zastosowana już w XIX wieku do kilku europejskich gatunków tego rodzaju ${ }^{77}$. Jej pochodzenie jest niejasne.

ston'oha 'stonoga murowa, Oniscus asellus; prosionek szorstki, Porcelio scaber'

Nazwa powstała jako złożenie słów sto i noga, w swym znaczeniu odwołująca się do mnogości odnóży owada. Wyraz występuje w większości języków słowiańskich, przy czym niektóre z nich (górnołużycki, czeski i bułgarski) uogólniły formę pierwotnie zdrobniałą: pol. stonoga, kasz. stonok, g.-łuż. stonóžka, czes. stonožka, st.-czes. stonoh, słowac. stonoha, stonožka, ukr. стоногa, dial. стонга, brus. станога, станожка, słoweń. stonoga, serb.-chorw. стонога, bułg. стонажка, maced. стонога, стоногалка, por. także ros. сороконожка 'stonoga ${ }^{78}$.

strykoz'a 'konik polny, Chorthippus dorsatus; pasikonik, Tettigonia viridissima'

Wyraz o pochodzeniu wschodniosłowiańskim ze zróżnicowaną semantyką w języku białoruskim i ukraińskim, por. ros. стрекоза 'ważka', ukr. dial. стрекоза 'konik polny', стрикоза 'ważka', brus. страказа, стрыказа 'ważka, konik polny'. Najbardziej wiarygodna wersja dotycząca etymologii nazwy wskazuje na jej związek ze st.-rus. czasownikiem строкотати 'wydawać powtarzający się krótki trzeszczący odgłos' powstałym od mроскотати 'trzeszczeć' poprzez szereg uproszczeń czasownika prefiksalnego възтроскотати ${ }^{79}$. Staroruskie mроскотати pozostaje $\mathrm{w}$ bliskim związku z i.-e. pierwiastkiem dźwiękonaśladowczym * (s)treig'szypieć, trzeszczeć, gwizdać' 80 . Owad został więc nazwany od szumu skrzydeł

\footnotetext{
${ }^{76}$ М. Фасмер, Этимологичекииі словарь..., т. III, с. 669; Еөимологічний словник украйнської.., T. 5, c. 304.

${ }^{77}$ K. Smagowicz, Mantichora. Etymologiczny stownik nazw zwierząt, Kraków 2004, s. 172.

${ }^{78}$ Zob.: W. Budziszewska, Stowiańskie stownictwo..., s. 161.

79 П. Я. Черных, Историко-эмиммологический словарь современного рускког язика, т. II, Москва 1999, с. 208.

${ }^{80}$ Етимологічний словник украйньк ї.., т. 5, с. 437.
} 
przypominającego lekki, głuchy trzask. Nazwa pierwotnie odnosiła się do ważki, jednak ze względu na podobieństwo odgłosu wydawanego przez latającego konika polnego w części gwar białoruskich i ukraińskich obecnie jest używana także do oznaczania tego owada. W znaczeniu 'ważka' leksemu strykoz'a na omawianym terenie nie odnotowano.

ščyp aunka 'skorek pospolity, Forficula auricularia'

Specyficzna nazwa gwarowa utworzona od czasownika ščyplat'i 'szczypać’. U podstawy znaczenia leży czynność szczypania szczypcami, w które wyposażona jest tylna część tułowia tego owada i których używa on w obronie przed napastnikiem. Poza przejściowymi gwarami białorusko-ukraińskimi znana jest także gwarom białoruskim północnej Białostocczyzny.

\section{šeršen' 'szerszeń, Vespa crabro'}

Wyraz o charakterze ogólnosłowiańskim, sprowadza się do prasłow. postaci *şršsenb. Etymolodzy odnajdują w nim i.-e. pierwiastek * (s)ker- 'ciąć, kłuć, żgać', co świadczyłoby o pierwotnym znaczeniu 'tnący, żądlący owad' ${ }^{81}$. Przegląd współczesnych form słowiańskich wskazuje na ich zróżnicowanie fonetyczne, por. pol. szerszeń, st.-pol. sirszeń, sierszeń, kasz. šěršèn, połab. sarsén, d.-łuż., g.-łuż. šeršen, czes., słowac. sršĕn, ros. иериень, ukr. иериень, brus. шэриєань, słoweń.

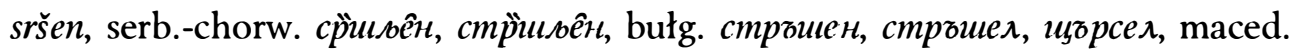
стрищен. Porównanie przytoczonych postaci nazwy szerszenia pokazuje, że największą ewolucję przeszła ona $\mathrm{w}$ grupie bułgarsko-macedońskiej i częściowo w języku serbochorwackim ${ }^{82}$. Najbliższe odpowiedniki nazwy tego owada odnajdujemy w litew. širšuñ, širšé, širšllyss, šiřšinas 'duża osa, szerszeń', łot. sirsenis, st.-prus. sirsilis 'szerszeń' ${ }^{83}$. W polszczyźnie nagłosowe $s z$ - pojawiło się najprawdopodobniej w wyniku upodobnienia na odległość $s-s z>s z-s z$. W językach wschodniosłowiańskich początkowe $\check{s}$ - obecne jest już w formach staroruskich: иьриень, иєериень obok сьриень.

švet 'kornik drukarz, Ips typographus'

Nazwa powstała zapewne od etnonimu Szwed 'mieszkaniec Szwecji, przedstawiciel narodu szwedzkiego, ${ }^{84}$. W znaczeniu 'owada żerującego pod korą drzew' odnotowany także w gwarach białoruskich na Mohylewszczyźnie,

\footnotetext{
${ }^{81}$ W. Boryś, Stownik etymologiczny..., s. 602.

${ }^{82}$ W. Budziszewska, Stowianiskie stownictwo..., s. 144.

${ }^{83}$ М. Фасмер, Этимологический словарь..., т. IV , с. 432.

${ }^{84}$ Tamże, s. 418.
} 
Witebszczyźnie i Polesiu ${ }^{85}$. Motywacja znaczenia tej specyficznej nazwy gwarowej jest niejasna. Ponadto na Kaszubach spotykamy go jako nazwę na oznaczenie 'ważki ${ }^{86}$, a w gwarach rosyjskich okolic Pskowa posiada znaczenie 'karalucha liniejącego zimą i stającego się białym'.

'utruten' 'truteń, samiec pszczoły miodnej'

Nazwa pochodzi od prasłow. dial. *trgtınb, formacji sufiksalnej utworzonej od pierwotnej prasłow. formy ${ }^{*}$ trgtr przy pomocy przyrostka $*_{-b n v}<*_{-b n-j b} 87$. Ten dawny derywat spotykamy dziś w tym znaczeniu w pol. truteń, dawne trucień (choć znane są dialektalne formy trąd, trąt, tręd, tręt, trut), w całej grupie ruskiej: ros. трутень, ukr. трутень (także oboczna forma bezprzyrostkowa mруm), brus. mруцень, a także bułg. mәрmей i w znaczeniu 'trzmiel' w chorw. dial. trîtanj. Pierwotną postać morfologiczną kontynuują pozostałe języki słowiańskie, por. kasz. trgd, d.-łuż. tšut, g.-łuż. truta, st.-czes. trup, czes. trubec (także trít, trout w znaczeniu 'szkodliwy insekt; robak na kapuście'), słowac. trúd, słoweń. trót, serb.chorw. mpȳm, mpŷm, bułg. mpym, maced. mpym ${ }^{88}$. Pokrewne formy litew. trãnas 'truteń', łot. $\operatorname{tran}(i) s$ 'ts.' i dalsze st.-w.-niem. trëno, śr.-w.-niem. trëne, niem. Drohne 'ts.' pozwalają sprowadzić nazwę tego owada do i.-e. onomatopeicznego rdzenia *tren-, * $d^{h}$ ren- 'mruczeć, brzęczeć, buczeć', a pierwotne znaczenie określić jako 'ten, który brzęczy, buczy ${ }^{89}$. Forma gwarowa z nagłosową protetyczną samogłoską $u$, powstałą zapewne pod wpływem samogłoski rdzennej, jest innowacją dialektalną charakterystyczną wyłącznie dla białorusko-ukraińskich gwar przejściowych na Białostocczyźnie.

\section{$v^{\prime} \mid \tilde{i} \boldsymbol{d}$ ' $m a$ 'ćma, owad Frenatae'}

Nazwa owada pochodzi od apelatywu wiedżma, przeniesionego na ćmę w skutek wierzeń ludowych, traktujących o tym, jakoby czarownice potrafiły zmieniać się w motyle ${ }^{90}$, por. ros. бабочка 'motyl', ночная бабочка 'ćma', motywowane przekonaniem, że dusza zmarłego nadal żyje pod postacią motyla ${ }^{91}$. W znaczeniu 'ćma' występuje także w ukr. Bið̋Ma, a na Grodzieńszczyźnie brus.

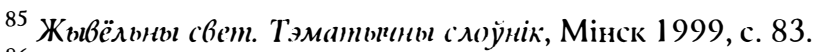

${ }^{86}$ Zob.: W. Budziszewska, Stowianiskic' stownictwo..., s. 159.

${ }^{87}$ W. Boryś, Stownik etymologiczny..., s. 645.

${ }^{88}$ W. Budziszewska, Stowianiskie stownictwo..., s. 71.

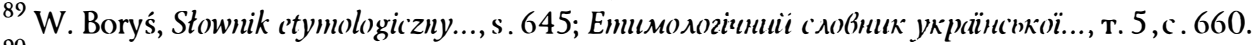

${ }^{90}$ A. Brückner, Stownik e'tymologiczny..., s. 345.

${ }^{91}$ М. Фасмер, Этиммлогиче'ский словарь..., т. I, с. 100.
} 
Ведзьма odnotowano jako określenie 'dużego motyla o ciemnym kolorze' ${ }^{\text {'2 }}$. Forma v'

voš 'wesz ludzka, Pediculus humanus'

Nazwa ogólnosłowiańska pochodząca od i-.e. *lüs- 'wesz' (por. zachowane w językach germańskich i celtyckich: niem. Laus, ang. louse, st.-isl. lūs 'wesz', wal. llau 'wszy') przekształconego (z powodu tabu) przez zanik *l- w prasłow. *vəšs, gdzie ${ }^{*} v$ - ma charakter protetyczny ${ }^{93}$ i obecnie występuje na terenie niemal całej Słowiańszczyzny, por. pol. wesz, dial. wsza, kasz. veš, všë, vša, d.-łuż. wěs, woš, g.-łuż. woš, czes. veš, słowac. voš, ros. Boutb, ukr. Bouı, Bouıa, brus. Bou, słoweń. ùs, serb.-chorw. Bàu, $\hat{y} u$, a także pierwotnie deminutywne bułg. Bzuıka, maced. Вouı $a^{94}$. Gw. voš nawiązuje do form wschodniosłowiańskich $\mathrm{z}$ wokalizacją jera $r$ (st.-rus. Bruıb) w postaci $o$.

vounk 'wołek zbożowy, Sitophilus granarius'

Formalnie wyraz należy odnieść do ogólnosłowiańskich jednostek leksykalnych, por. prasłow. ${ }^{*} v_{0}{ }^{\prime} k r$ i wywodzące się z niego współczesne pol. wilk, kasz.

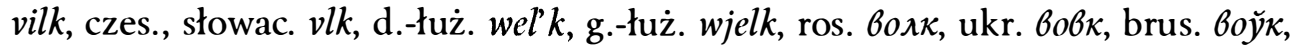
słoweń. vôtk, serb.-chorw. $B \hat{y} \kappa$, bułg. brлk, maced. Boлk. Wszystkie są tożsame pod względem znaczeniowym i oznaczają 'zwierzę Canis lupus'. Nazwom słowiańskim tego drapieżnika odpowiadają litew. villkas, łot. vilks, goc. wulfs, niem. Wolf, st.-ind. vṛkas, a także łac. lupus, grec. lýkos (z metatezą pod wpływem tabu). Wszystkie one kontynuują i.-e. *ullku ${ }^{u}$ - 'wilk', pochodzące od i.-e. pierwiastka *unel- 'rwać, szarpać'”5 . Znaczenie gw. vounk 'wołek zbożowy' jest charakterystyczne wyłącznie wschodniosłowiańskim gwarom Białostocczyzny. Leksem ten pozostaje w opozycji homonimicznej zarówno międzyjęzykowej (w szczególności do nazw wilka w językach ruskich), a także wewnątrzsystemowej (por. gw. vounk w znaczeniu (wilk'). Motywacja nazwy tego owada jest niejasna.

žuk 'żuk wiosenny, Geotrupes vernalis; żuk gnojowy, Geotrupes stercorarius'

Nazwa występuje w większości języków północnosłowiańskich (bez języka dolnołużyckiego i grupy czesko-słowackiej): pol. żuk 'chrząszcz Geotrupes', połab. zäuk 'krówka (gatunek chrząszcza)', g.-łuż. žuk 'owad Bruchus', ros., ukr., brus. жyא 'chrząszcz, żuk'. Prasłow. dial. *žukr 'chrząszcz' powstało od dźwięko-

\footnotetext{
${ }^{92}$ Жblßёльны çem..., c. 87.

${ }^{93}$ W. Boryś, Stownik etymologiczny..., s. 685.

${ }^{94}$ W. Budziszewska, Stowianiskie stownictwo..., s. 145.

${ }^{95}$ W. Boryś, Stownik etymologiczny..., s. 700.
} 
naśladowczego pierwiastka *žu- (por. ros. жyжжamb 'brzęczeć, bzykać', czes. žu$k a t i$, słoweń. žučati 'brzęczeć (o owadach)') przy pomocy przyrostka ${ }^{*}-k \mathfrak{z}$ pierwotnie jako nazwa czynności 'brzęczenie, bzyczenie', wtórnie - rezultat tej czynności 'to, co brzęczy, bzyczy' ${ }^{\text {'6 }}$. Niegdyś wyraz miał zapewne szerszy zasięg, o czym mogą świadczyć czes. žuka 'imię psa' czy bułg. жyжa 'brzęczeć (o owadach),97.

Poddane analizie etymologicznej gwarowe słownictwo z zakresu nazewnictwa owadów pozwala ując się w ramy klasyfikacji uwzględniającej pochodzenie poszczególnych jednostek leksykalnych. Najogólniej omawiany materiał językowy można podzielić na wyrazy występujące na obszarze całej Słowiańszczyzny, lub znacznej jej części, oraz nazwy owadów charakterystyczne tylko badanym białorusko-ukraińskim gwarom przejściowym na Białostocczyźnie. Osobną grupę tworzą zapożyczenia z języka polskiego. W przypadku niektórych leksemów granica zaproponowanego podziału jest czasami trudna do precyzyjnego określenia, bowiem grupy analizowanego słownictwa entomologicznego pod różnymi względami przenikają się wzajemnie.

Pierwszą część tak sklasyfikowanego materiału językowego stanowi leksyka prasłowiańska o zasięgu ogólnosłowiańskim, a także nazwy określone mianem wschodniosłowianizmów (rutenizmów) i północnosłowianizmów. Wśród warstwy słownictwa prasłowiańskiego pewną grupę stanowią wyrazy najstarsze, kontynuujące identyczne znaczeniowo formy praindoeuropejskie. Należą do nich: błox $a$, červ, $h n^{\dagger} i d a, m^{\prime} u x a$, os $a$ i voš. Prasłowiański charakter mają także: błošć̀ yca, xrušč, čm'iel', kl' iešč, kom 'ar, muol', 'ovad, pa 'uk i šleršen'. Na gruncie ogólnosłowiańskim

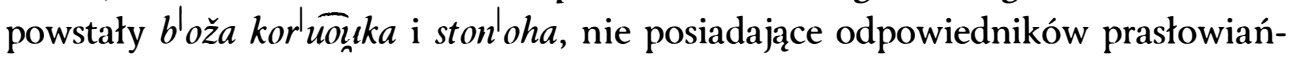
skich.

Określenie „wschodniosłowiańskie” otrzymały nazwy o cechach ruskich odnoszących się do różnych płaszczyzn językowych. Do wschodniosłowiańskich innowacji semantycznych należą: bz'żiel', p'etryk (petro), švet, $v^{\prime} \mid{ }_{i e d}$ ma. Wyrazy červ'ak, m'oška, muravel', 'ovaden' choć poprzez morfemy rdzeniowe nawiązują do leksyki ogólnosłowiańskiej, jednak wyróżniają się spośród niej ruskimi cechami fonetyczno-morfologicznymi. Kuzlaka i strykoz a to rutenizmy leksykalne.

Słownictwo pochodzenia wschodniosłowiańskiego jest także zróżnicowane pod względem terytorialnym i czasowym. Niektóre jednostki leksykalne, poza omawianymi gwarami, odnotowano jedynie na białorusko-ukraińskim ('ovaden', $p^{\prime}$ etryk, petrlo, v'ied'ma) bądź tylko białoruskim (bz'ż iel', kuzlaka, švet) obszarze językowym. Czas pojawienia się wymienionych nazw w systemie nazewniczym owadów jest różny, często trudny do określenia. Niektóre z nich ( $m$ loška,

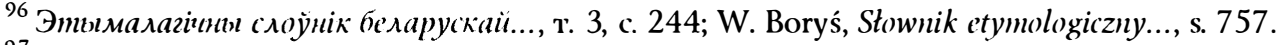

${ }^{97}$ W. Budziszewska, Stowianiskic stownictwo..., s. 147-148.
} 
'ovaden') sięgają epoki prasłowiańskiej, inne kształtowały się w okresie staroruskim (murav'el', strykoz'a) lub już w fazie rozwoju poszczególnych języków

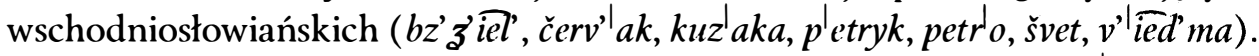

Charakter północnosłowiański mają jedynie dwie nazwy: matyl $l^{\dagger} i c y$ i žuk.

Druga, znaczna ilościowo, grupa leksyki entomologicznej to gwarowe jednostki rodzime, charakterystyczne wyłącznie dla omawianego materiału językowego. Wśród nich należy wyodrębnić innowacje leksykalne takie jak: bzy (m)kot uxa, kus'ušča m'uxa, pol'iz'oxa, ščppaunka; innowacje semantyczne: kov'al', kruot, vouk oraz innowacje fonetyczno-morfologiczne: mat'ytka, 'utruten'. Dwa ostanie typy mają charakter przejściowy pomiędzy obiema grupami analizowanej leksyki, są bowiem formalnie lub znaczeniowo wyrazami prasłowiańskimi.

Podobnie zróżnicowane pod względem językowym i czasowym są zapożyczenia z języka polskiego. Dawne pożyczki, sięgające w mniejszym lub większym stopniu swym pochodzeniem epoki prasłowiańskiej (b'edronka, boyk, g’es, p̌šcoł a), i nowsze, powstałe na gruncie języka polskiego ( $c^{\prime} m a, r o b^{\prime} a k, s^{\prime} l^{\prime} i p^{\prime} a k$, st'onka), trafiały do gwar wschodniosłowiańskich Białostocczyzny na różnych etapach rozwoju wzajemnych wpływów językowych. Mimo pochodzenia bałtyckiego, do leksyki zapożyczonej z polszczyzny trzeba odnieść także nazwę prus ak.

Zakres językowy tych polonizmów również jest różny. Większość z nich stanowią zapożyczenia leksykalne. Należą do nich: bojk, c'ma, g’es, prus'ak, roblak, st'onka. S'l'ip ak przejął z polskiego jedynie warstwę semantyczną, a nazwy b'edronka i pščot' a są polonizmami fonetyczno-morfologicznymi: pierwsza $\mathrm{z}$ uwagi na przyrostek -onka, druga ze względu na rozwój nagłosowej grupy spółgłoskowej w postaci $p \check{s} \check{c}$ -

Dokonana analiza etymologiczna pozwala zauważyć, że znacząca większość gwarowych terminów entomologicznych ma dawny, prasłowiański charakter. Fakt ten nie powinien dziwić, gdyż owady towarzyszą człowiekowi od zarania dziejów, a ich oznaczenia bytują w mowie zapewne od czasu opanowania przez homo sapiens umiejętności komunikacji językowej.

Próba tak ukierunkowanej charakterystyki lingwistycznej analizowanych jednostek leksykalnych objęła swoim zasięgiem jedynie wąski wycinek słownictwa faunistycznego. Należy uznać ją za skromny początek trudnych, żmudnych, praco- i czasochłonnych badań etymologicznych nad leksyką gwarową Białostocczyzny.

\section{Wykaz skrótów:}

afg. - afgański

ang. - angielski

awest. - awestyjski połab. - połabski

por. - porównaj

prasłow. - prasłowiański 


$\begin{array}{ll}\text { bałt. - bałtycki } & \text { ros. - rosyjski } \\ \text { brus. - białoruski } & \text { sebr. - serbski } \\ \text { bułg. - bułgarski } & \text { serb.-chorw. - serbochorwacki } \\ \text { chorw. - chorwacki } & \text { słowac. - słowacki } \\ \text { czes. - czeski } & \text { słoweń. - słoweński } \\ \text { daw. - dawny } & \text { st.-czes. - staroczeski } \\ \text { dial. - dialektalny } & \text { st.-ind. - staroindyjski } \\ \text { d.-łuż. - dolnołużycki } & \text { st.-iran. - staroirański } \\ \text { g.-łuż. - górnołużycki } & \text { st.-irl. - staroirlandzki } \\ \text { goc. - gocki } & \text { st.-isl. - staroislandzki } \\ \text { grec. - grecki } & \text { st.-łuż. - starołużycki } \\ \text { gw. - gwarowy } & \text { st.-pol. - staropolski } \\ \text { i.-e. - indoeuropejski } & \text { st.-prus. - staropruski } \\ \text { ind. - indyjski } & \text { st.-rus. - staroruski } \\ \text { kasz. - kaszubski } & \text { st.-w.-niem. - staro-wysoko-niemiecki } \\ \text { litew. - litewski } & \text { szwedz. - szwedzki } \\ \text { łac. - łaciński } & \text { śr.-irl. - średnioirlandzki } \\ \text { łot. - łotewski } & \text { śr.-w.-niem. - średnio-wysoko-niemiecki } \\ \text { maced. - macedoński } & \text { ts. - to samo } \\ \text { niem. - niemiecki } & \text { ukr. - ukraiński } \\ \text { pers. - perski } & \text { wal. - walijski } \\ \text { pol. - polski } & \end{array}$

\title{
ON THE ORIGIN OF INSECTS' NAMES IN BELARUS-UKRAINIAN TRANSITIONAL DIALECTS IN BIAEOSTOCCZYZNA
}

\author{
S u m mary
}

The article includes an etymological analysis of a local dialect vocabulary in the scope of insects' names. The research is based on the linguistic material collected directly in the area and excerpted from Atlas gwar wschodniostowianskich Biatostocczyzny /Atlas of Eastern Slavonic Dialects of Biatostocczyzna/, comprising the area of Belarus-Ukrainian transitional dialects in Białostocczyzna. The description of the entomological lexis origin implies its considerable differentiation. Moreover, it enables to distinguish words of a generally Slavonic nature as well as lexical chunks/units occurring only in the researched dialects. Borrowings from Polish make a separate group. 